\title{
STUDENTS' POINT OF VIEW ON THE USE OF WHATSAPP GROUP TO ELEVATE WRITING ABILITY
}

\author{
Evyta Tri Handayani ${ }^{1}$, Dyah Aminatun ${ }^{2}$ \\ Universitas Teknokrat Indonesia ${ }^{1,2}$ \\ evytatrihandayani15@gmail.com¹,dyah_aminatun@teknokrat.ac.id ${ }^{2}$
}

\begin{abstract}
Received: 10 October 2020
Accepted: 2 December 2020

Abstract

English has been an important language nowadays. The role of the English language also has become the qualification of many people. However, many students state that English is not an easy language to master especially in Indonesia. Teachers also find it as a challenge in teaching English in Indonesia. They must have the appropriate technique and media for the students. One of the media that can be used by teachers to teach and engage students' participation in learning English is WhatsApp. This application is also popular among the students as instructional learning mobile medium, including as a teaching medium to teach writing for students. Besides it is easy to operate, many students are familiar with it. This research aimed to find out students' perspectives towards the use of WhatsApp group in improving students' writing ability. This study applied a descriptive qualitative study with 37 students of the English Education study program as the participants. The data instrument used in this research were questionnaire and interview. The findings show that teaching writing by using the WhatsApp group can bring positive effects and benefit during the teaching and learning process. Besides that, it can also develop students' writing ability. This result is supported by students' opinions which state many good responses to this media rather than bad responses. Moreover, the result also shows that the WhatsApp group is one of the appropriate learning platforms for education in Indonesia.
\end{abstract}

Published: 30 December 2020

Keywords: students' perspective, WhatsApp group, writing ability

\section{To cite this article:}

Handayani, E. T. \& Aminatun, D. (2020). Students' Point of View on the Use of WhatsApp Group to Elevate Writing Ability. Journal of English Language Teaching and Learning, 1(2), 31-37.

\section{INTRODUCTION}

English skill is important for everyone living in this globalization era to compete with others since English is used as a tool of communication internationally. It cannot be denied that English has become an important language in Indonesia since it is taught at almost every school level. Ayu \& Indrawati (2020) stated that English has been considered a foreign language in Indonesia. Moreover, it has a special place in the school curriculum. Concerning that, Indonesia has been carrying out teaching English as a foreign language at schools which is taught in primary school, junior high school until senior high school. However, teaching English in Indonesia is not an easy thing. The teacher must have an appropriate technique to gain students' attention during the teaching process. Similar to the teachers, for the students, although they have studied English since elementary school, some of them still face some difficulties until the upper grade.

As it is mentioned in the beginning that teaching English is not an easy thing, the teacher needs to think more creatively in delivering the material. Since the era nowadays pushes everyone to deal with technology, the teacher also needs to embrace it and apply it in the class. According to Ir. H. Joko Widodo, Industrial Revolution 4.0 has pushed technological innovations that have a fundamental disruption or change impact on people's lives. Besides, the researcher can conclude that if we look at the perspective of the education world, it means that the education world in 4.0 describes various ways to integrate cyber technology both physically and into learning. Oktaviani \& Mandasari (2020) argued that facing industrial revolution 4.0 requires university students to provide themselves with a skill that they can use to compete with machines or computers. One of the skills is a negotiation which involves mastering language, especially English as a means of international communication. Industrial revolution 4.0 has impacted education and causes the changing of teaching and learning methods. The development of technology affects the changing of the teaching and learning process and provides the various learning strategies which are suitable for the learners' characteristics to make them become independent learners (Putri \& Sari, 2020; 
Sari, 2020). Lecturers cannot use their traditional way of teaching and learning anymore since students' characteristics also change into technology-addict learners.

Applying technology in learning English nowadays is one of the ways to improve the way of teaching of the teacher because it can stimulate students' enthusiasm (Oktaviani \& Desiarti, 2017). Since it is a complicated thing to teach a language, the teacher needs technology to support them to build the skill. Studying a language to master it is studying skills. Like other language skills, four skills should be mastered when studying the English language; they are listening, speaking, reading, and writing. All of those skills complement each other; nothing is more important than others. The writing skill especially has become very important in the education field. Students need to be exercised and trained to have a good writing skill. According to Citraresmana (2018), writing is one of the language skills; through writing, we can observe one's language ability. It is believed that writing is a kind of reflection of the writer's cognition since that writing will represent the writer him or herself. Through writing students' can deliver their idea and expression. However, still, a student's writing skill is not something that can be taken for granted by teachers (Gulö \& Rahmawelly, 2018). Therefore, the teacher can use technology to support both themselves and their students to develop their writing skills with the role of technology.

As is stated by Aminatun (2019), the role of technology in the education system has influenced the way of teaching from conventional to modern way. Technologies nowadays mostly bring positive effects toward the education world especially in learning English. One of the social-networking applications which are appropriate and popular among the students as instructional learning mobile medium is WhatsApp. WhatsApp application has emerged as one of the new potential social networking applications that are designed on all current types of devices and operating systems to run both on mobile devices and computers (Bouhnik \& Deshen, 2014). Moreover, Justina (2016) applied WhatsApp to enhance reading and writing skills at the undergraduate college level at Osmania University India. The result of her study showed that the use of WhatsApp was very essential to identify what their students enjoy and utilize it to engage them in language development, especially reading and writing which slow learners find difficult when it was conducted conventionally. Another study conducted by Kheryadi (2017) implemented WhatsApp as a medium of English language teaching by distributing some questions to the subject of his study. The result revealed that the students felt confident, independent, enthusiastic, and had a positive attitude to learn English using the WhatsApp application. Sari \& Putri (2019) also researched that the findings present the multitude of views that most students significantly showed the positive result to use WhatsApp Group in their writing class. By experiencing WhatsApp Group Chat in their learning writing, the students admitted that it is user-friendly and easy to use because it can intensify the interaction with the other group members during the class and after the class, be effective in submitting the writing assignment by uploading the file in the group, get the lecturer's feedback directly after submitting the writing assignment, and freely ask and share the writing materials (Sari \& Putri, 2019).

In this research, the researcher brought WhatsApp to writing class as a medium to teach writing since it can help student's ability to write the text-based instruction on the application. WhatsApp application itself has a special feature to create a specific group to bind the members and intimate the interaction among teacher and students relating to the course matters. Besides, during the learning process of writing through WhatsApp, the students can explore the idea, show expression, and increase the vocabulary. The students are also trained to learn responsibility, solve the problem, be collaborative, and skilled in technology. Based on the background of the study, the researcher formulates the statement of the problem as follows: How is students' point of view on the use of WhatsApp Group in writing? In the end, the result of this study will fulfill its objective that is to analyze and find out students' responses on the use of WhatsApp as their learning medium to elevate their writing ability.

\section{METHOD}

This research applied descriptive qualitative as a research method. It means that the researcher described the results of the analysis in the form of words. As Kuswoyo \& Susardi (2016) stated that qualitative research is characterized by verbal description of its data. The participants involved were 37 students of the English Education study program, Faculty of Arts and Education, Universitas Teknokrat Indonesia. The data were collected from two instruments - a questionnaire and an interview. The questionnaire consisted of 10 questions that asked about the role of the WhatsApp group in learning writing. In this study, the researcher distributed questionnaires in the form of Google Form to collect data, while the interview was conducted with the students who joined the class of Writing. The interview was conducted for some respondents to support the data of the questionnaire.

\section{FINDINGS AND DISCUSSION}

The results of this study from exploring students' perspective toward the use of WhatsApp group in improving writing ability are presented below: 


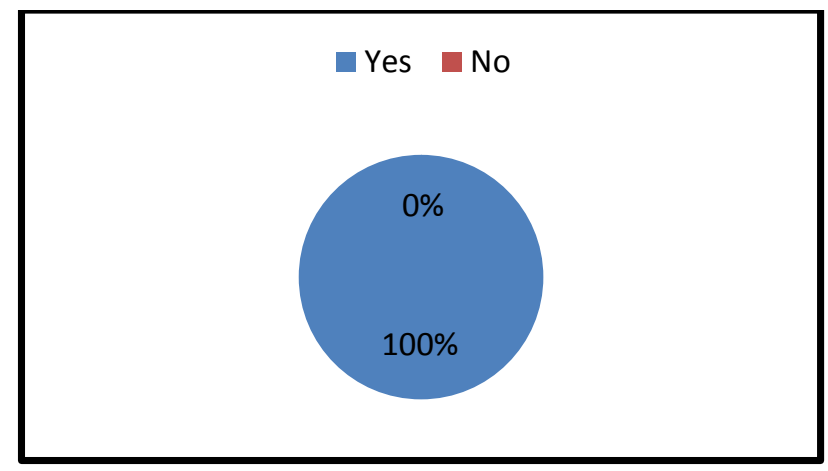

Figure 1. Students' experience toward the use of WhatsApp group

The researchers provided the participants with the first question, "Have you ever learned using WhatsApp Group?". As a result of the first question, all students which consist of 37 participants stated that they all have used the WhatsApp group during the learning process. Moreover, the researchers also conducted interviews with several participants to better know or explore students' opinions about their experiences using the WhatsApp group. The interview result revealed that many students showed positive responses to the use of WhatsApp in the class. Some of the students' responses are seen in the following extract.

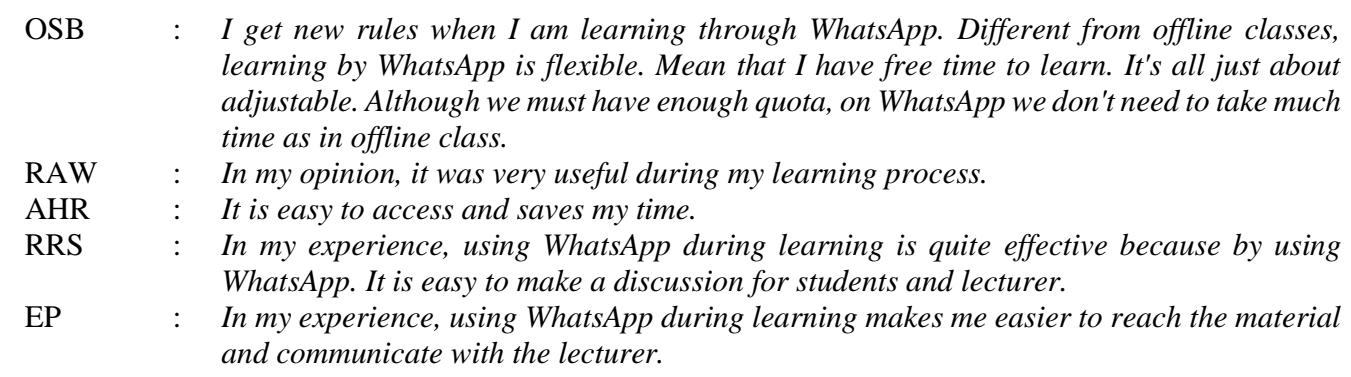

From the interview, it can be seen that using WhatsApp as a learning medium brings some positive effects to the students, such as flexibility and adjustability, especially in terms of time. It is easy to have a discussion and communicate with the lecturer or other students because everyone has a chance to do it, and easy to get the materials. WhatsApp provides a feature in which people can share files or documents that can be downloaded by the group member in WhatsApp. Therefore, it enables the lecturer to share the materials to be distributed to their students in the group. Sending study materials through WhatsApp Group ensures that everyone gets the message (Hamad, 2017). Experiencing WhatsApp Group in learning writing makes it easy to share the writing materials and submit the assignment by uploading the file in the group. Besides that, using WhatsApp can facilitate or create a chance for learning and communication as well, as it is the most common to the students and they always have their smartphones in their hands, besides it is free to activate the application.

\section{Students' perspective towards the use of WhatsApp group in elevating their writing ability}

The table below shows the results of students' responses to the use of WhatsApp group toward their writing ability from the view of educational aspects especially during learning the English language, especially writing skill. There are nine questions given to the students in the questionnaires. The table below shows the result for each item of the questionnaire. The detailed results can be seen as follows:

Table 1. Students Responses to the use of WhatsApp Group in Writing Ability

\begin{tabular}{clcc}
\hline No & \multicolumn{1}{c}{ Questions } & Yes & No \\
\hline $\mathbf{1}$ & Do you think that activities or practices from the WhatsApp group are & $83.8 \%$ & $16.2 \%$ \\
& beneficial especially for your writing ability? & & \\
$\mathbf{2}$ & Does the WhatsApp group make a boundary for your writing ability? & $24.3 \%$ & $75.7 \%$ \\
$\mathbf{3}$ & Do you think that learning with the WhatsApp group is difficult? & $37.8 \%$ & $62.2 \%$ \\
$\mathbf{4}$ & Does WhatsApp develop your writing ability during the learning process? & $67.6 \%$ & $32.4 \%$ \\
$\mathbf{5}$ & Do you think that WhatsApp group creates interaction among students? & $83.8 \%$ & $16.2 \%$ \\
$\mathbf{6}$ & Is WhatsApp group chat time-wasting and time-consuming? & $59.5 \%$ & $40.5 \%$ \\
$\mathbf{7}$ & Does the WhatsApp group increase your grammar and vocabulary? & $70.3 \%$ & $29.7 \%$ \\
$\mathbf{8}$ & Is WhatsApp group an appropriate platform to develop students' writing & $70.3 \%$ & $29.7 \%$ \\
& ability? & & \\
\hline
\end{tabular}




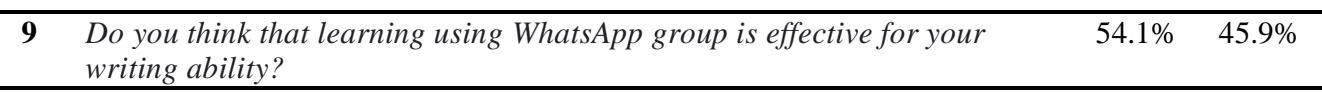

The table above shows the result of students' perception on the use of WhatsApp group toward their writing ability in the learning process. The first question of this questionnaire shows that around $16.2 \%$ of students think that activities or practices from the WhatsApp group did not bring benefits because it is difficult to understand. However, $83.8 \%$ of students think that activities or practices from WhatsApp Group give benefits especially in the writing ability because from the activities students did, the lecturer can give feedback directly after submitting the writing assignment and the students can freely ask about the mistake and how to do it properly and correctly. It means that WhatsApp can bring a positive impact on the students' writing ability. This result is in line with the interview that the researcher has conducted. The responses could be seen in the following extracts.

\begin{tabular}{|c|c|c|}
\hline DA & & $\begin{array}{l}\text { Based on my opinion toward the use WhatsApp for my writing ability, the benefit that I get } \\
\text { from learning through WhatsApp is to be more active in writing because my lecturer asked } \\
\text { me to write the comments of assignments for my friends with using English, chatting with } \\
\text { my friends with using English also in the group. }\end{array}$ \\
\hline AHR & & $\begin{array}{l}\text { It has benefits for my writing skill because I could see and review my peers' works which } \\
\text { will give an improvement. }\end{array}$ \\
\hline OSB & & $\begin{array}{l}\text { The benefit that I can get from learning through WhatsApp, there's not limited time rather } \\
\text { than offline class and I have lots of time to improve my writing ability because before I did } \\
\text { assignment or activities I can browse the lot at that time. }\end{array}$ \\
\hline SLH & & $\begin{array}{l}\text { The benefit of using WhatsApp group in writing for me is, it makes me easier to understand } \\
\text { the new vocabulary without look for the meaning so it gave me improvement toward } \\
\text { writing skill. For example, the teacher gave the material and my friend asked her about } \\
\text { the material, the teacher explained that by using the teacher's words. So, I can guess about } \\
\text { it. }\end{array}$ \\
\hline
\end{tabular}

The second question shows there are $24.3 \%$ of students think that the WhatsApp group makes a boundary for students' writing ability. It is because sometimes the material is too difficult and the connection to browse is too poor. Moreover, there are $75.7 \%$ students stated of the second question which WhatsApp group never made boundary for students' writing ability because, from the implications on pedagogies, the support of WhatsApp in learning process allows the users direct access to numerous of online resources and more focus on the students' creativity, autonomy, and their responsibility on their learning (Ifenthaler \& Schweinbenz, 2016).

The third question reveals that $62.2 \%$ of students think that learning using the WhatsApp group is not difficult for students. They stated that it was accessible and they did not find any difficulties to complete the task given by the lecturer and agreed that WhatsApp made their learning process easier than the traditional one conducted in the class. However, $37.8 \%$ of students think that learning with the WhatsApp group is difficult because students did not understand the material. It will be better for the students can ask the question directly to the lecturer and the lecturer explains it. Besides that, sometimes students' got distracted easily when they are on their phones (Sari \& Putri, 2019).

From the findings, it can be seen that most students give positive responses to WhatsApp in their writing learning process. The students stated that the WhatsApp group gives them positive effects on the learning process and developing their writing ability. As it is stated in the fourth question, there are $67.6 \%$ of students stated that learning by using Whatsapp can enable students to correct their mistakes immediately. It can give a very significant improvement for students' writing since they know their mistakes and try to make them better. Through WhatsApp, students can share their ideas, opinion, or thought in which it can more develop students' writing ability. However, there are $32.4 \%$ of students assumed that sometimes there are materials that are tough to be understood if students just read the materials. As a result, students need the exact explanation of it. This result is also supported by the interview with some students. The responses could be seen in the following extracts.

$\begin{array}{ll}\text { RRS } & : \begin{array}{l}\text { By sharing opinion and idea of the topic of writing in WhatsApp group, it is easy for the } \\ \text { student to discuss how to develop their writing topic with the teacher or discuss with their } \\ \text { friends. }\end{array} \\ \text { DA } & : \begin{array}{l}\text { In WA group sometimes we actively interact with other friends when the teacher provides } \\ \text { the opportunity to express ideas to his students. }\end{array} \\ \mathrm{EP} & : \begin{array}{l}\text { Simple answer is like this one. When someone asks me a question in English, I try to answer } \\ \text { it in English. So unconsciously, through this, I develop my writing ability because I need }\end{array} \\ \text { to type it. } & \end{array}$ 
A significant result showed in the fifth question with $83.8 \%$ which stated that WhatsApp group can create interaction among students because by using WhatsApp. Students can discuss with their friends, interact with friends, such as doing peer correction or commenting toward each other's' work. Moreover, WhatsApp also can enhance the interaction with the other group members or lecturers during the class and after the class. As is stated by Sari \& Putri (2019), students should be provided with an interactive learning environment where they can actively engage in the teaching and learning process and encourage their interaction with the facilitator and other peers. Creating a dialogue between the students enables them to share information and work as a team. These things occur when students begin to help each other, answer each other's questions, and share their discoveries. WhatsApp can contribute to the interpersonal relationship between lecturers and students. Students feel more comfortable about approaching their lecturers. As stated by Bouhnik \& Deshen (2014) that before having the WhatsApp group, students did not feel comfortable to call, they said that they do not want to bother. Then, they started to write privately on WhatsApp, they felt comfortable to write any time, any question.

The findings from the sixth question of this questionnaire show that around $40.5 \%$ of students think that WhatsApp group chat is time-wasting and time-consuming because many chats come up and it will be trouble if the message is pending in submitting the assignment. However, 59.5\% of students think that WhatsApp group chat is not time-wasting and time-consuming. Using Whats App groups to communicate saves a lot of time rather than trying to send the message through other means and increases class efficiency by reminding students what they need to bring and where everything occurs (Bouhnik and Deshen, 2014). Moreover, students can study every time and everywhere then students can use WhatsApp group as their make-up class if the lecturer can't attend the class.

Next, there are $70.3 \%$ of students agree that the WhatsApp group can increase grammar and vocabulary which showed by the seventh question. It is because the lecturers correct spelling and grammar mistakes as soon as occur. They comment briefly and immediately, so the mistake will not strike roots (Alfiyani, 2013). Learning writing through these cross-platform instant messaging might broaden the student's self-learning experiences (Sari $\&$ Putri, 2019). However, there are $29.7 \%$ of students felt that the WhatsApp group does not increase grammar and vocabulary because students themselves are still unable to understand and grasp what was explained by the lecturer.

Moreover, the eighth question also shows that $70.3 \%$ of students think that the WhatsApp group is an appropriate platform to develop students' writing ability. Since all students and also lecturers are in one group, if the students make a mistake in writing, other students will be given a chance to correct the writing to develop students' writing. In this case, the lecturer will give additional comments and corrections when needed. There is also a discussion about writing with the lecturer without limited time. Therefore, students are having a high chance to keep asking and get information related to what they need in their writing. WhatsApp enables learning beyond the classroom's borders (Bouhnik \& Deshen, 2014). However, there are $29.7 \%$ of students also revealed that there were some technical problems found when they used the WhatsApp group chat such as abundant chats, poor signal, and junk notification.

The last, there are $45.9 \%$ of students think that learning by using WhatsApp group cannot bring effectiveness for students' writing ability because there is no depth explanation of the material in the WhatsApp group, as a result, it makes less effective. Moreover, $54.1 \%$ of students think that learning with the WhatsApp group is effective as a medium to study writing. As stated by Alsaleem (2013), WhatsApp electronic journaling a new application in smartphones that has a significant effect on students. The results indicate a significant difference and significant improvements in vocabulary word choice and some writing components. It can be said that using the WhatsApp group has brought positive impacts to students during the learning process of writing.

\section{CONCLUSION}

From the explanation above, it can be concluded that learning using WhatsApp group in writing can produce positive effects and benefits for the students. Students believe that the WhatsApp group can develop their writing ability. It is seen from the responses of most students in the writing class who give a good response to this medium. Moreover, the students also admit that the WhatsApp group affects the improvement of their writing ability because they can do peer correction, give comments, and have a discussion about the topic with others. Using WhatsApp can also build interaction among students because they can share knowledge and information. Besides, every student has already known how to use WhatsApp well and familiar with it. The popularity of the WhatsApp group has been exploited to be an educational powerful medium by learners in any area of language. So, it is not difficult to use during the learning process. Seeing the result of this research, it can be implied that the use of WhatsApp group can improve students' writing ability. Besides, it can also be an appropriate platform for education in Indonesia, especially in this COVID-19 pandemic. It is hoped that the researcher in the future can develop the research with different settings and samples, so this research can give more insight related to the use of WhatsApp in the teaching and learning process. 


\section{REFERENCES}

Ahmad, M. R. (2018). The Use of Technology in English Language Learning: A Literature Review. International Journal of Research in English Education, 3(2), 116-125.

Alfiyani. L. M. (2013). An Analysis Of Grammatical Errors In Writing Among The Second Semester Students Of English Department Of Yogyakarta State University In The Academic Year Of 2011/2012. A thesis. Retrieved from: https://eprints.uny.ac.id/25706/1/Lulu\%20Meilina\%20Alfiyani\%2006202244055.pdf.

Alsaleem, A. B. I. (2013). The Effect of "WhatsApp" Electronic Dialogue Journaling on Improving Writing Vocabulary Word Choice and Voice of EFL Undergraduate Saudi Students. Arab World English Journal, 4(3), 213-225.

Aminatun, D. (2019). ICT in University: How Lecturers Embrace Technology for Teaching. JURNAL SMART, 5(2), 71-80.

Aminatun, D., \& Oktaviani, L. (2019). Memrise: Promoting Students' Autonomous Learning Skill through Language Learning Application. Metathesis: Journal of English Language Literature and Teaching, 3(2), 214-223.

Ayu, M., \& Indrawati, R. (2019). EFL Textbook Evaluation: The Analysis of Tasks Presented in English Textbook. Teknosastik: Jurnal Bahasa dan Sastra, 16(1), 21-25.

Bouhnik, D., \& Deshen, M. (2014). WhatsApp Goes to School: Mobile Instant Messaging between Teachers and Students. Journal of Information Technology Education: Research, 13, 217-231. Retrieved from: http://www.jite.org/documents/Vol13/JITEv13ResearchP217-231Bouhnik0601.pdf.

Citraresmana, E. (2018). English Language Competence of Secretary Students through Report Writing: Corpus-Based Study. Teknosastik: Jurnal Bahasa dan Sastra, 16(1), 1-8.

Dewi, S. R. (2019). Utilizing WhatsApp Application for Teaching Integrated English (A Case Study at University of Technology Yogyakarta). Refleksi Edukatika: Jurnal Ilmiah Kependidikan, 9(2), 165-171.

Dumanauw, A. (2018). The Use of WhatsApp Application to Teach Writing of Recount Text. Jurnal Pendidikan dan Pembelajaran Katulistiwa, 12(7), 1-8.

Gulö, I., \& Rahmawelly, T. V. (2018). An Analysis of Omission in Students' English Writings. Teknosastik: Jurnal Bahasa dan Sastra, 16(2), 55-59.

Hamad, M. (2017). Using WhatsApp to Enhance Students' Learning of English Language "Experience to Share". Canadian Center of Science and Education, 7(4), 74-87.

Hardyanthi, T., Ghozali, F., \& Wahyu, M. (2019). Facing the Industrial Revolution 4.0: Taiwanese and Indonesian Perspective. Journal UMY: Indonesian Comparative Law Review, 1(2), 94-102.

Ifenthaler, D., \& Schweinbenz, V. (2016). Students' Acceptance of Tablet Pcs in the Classroom. Journal of Research on Technology in Education, 48(4), 306-321.

Justina, M. (2016). Use of WhatsApp to Enhance Reading and Writing skills at Undergraduate College Level. Journal of Language in India, 16, 47-60.

Kheryadi. 2017. The Implementation of WhatsApp as a Media of English Language Teaching. Loquen English Studies Journal. 10(2), 1- 14.

Kuswoyo, H., \& Susardi. (2016). Thematic Progression in EFL Students' Academic Writings: A Systemic Functional Grammar Studi. Teknosastik: Jurnal Bahasa dan Sastra, 14(2), 39-45.

Lestari, M., \& Wahyudin, A. Y. (2020). Language Learning Strategies of Undergraduate EFL Students. Journal of English Language Teaching and Learning, 1(1), 25-30.

Merriam, S. B. (2009). Qualitative Research: A Guide to Design and Implementation.USA: John Wiley \& Sons, Inc.

Oktaviani, L. \& Desiarti, E. (2017). A Lecturer's and Students' Perspective toward Ethnic Snake Game in Speaking Class at Universitas Muhammadiyah Malang. Teknosastik: Jurnal Bahasa dan Sastra, 15(2), 53-59. DOI: https://doi.org/10.33365/ts.v15i2.98

Oktaviani, L., \& Mandasari, B. (2020). Powtoon: A Digital Medium to Optimize Students' Cultural Presentation in ELTClassroom. Teknosastik: Jurnal Bahasa dan Sastra, 18(1), 33-41.

Putri, E., \& Sari, F. M. (2020). Indonesian EFL Students' Perspectives on Learning Management System Software. Journal of English Language Teaching and Learning, 1(1), 20-24.

Rahmawati, F. (2017). The Effectiveness of Using WhatsApp to Improve Writing Ability In Announcement Text At The Tenth Grade Students Of Sman 1 Klirong. A Thesis, Retrieved from http://repository.umpwr.ac.id:8080/bitstream/handle/123456789/1377/132120189-Faida\%20Rahmawati.pdf.

Sari, F. M. (2016). Internet-Based Materials in Enhancing College Students' Writing Skill Viewed from Their Creativity. Teknosastik: Jurnal Bahasa dan Sastra, 14(1), 41-45.

Sari, F. M. (2020). Exploring English Learners' Engagement and Their Roles in the Online Language Course. Journal of English Language Teaching and Linguistics, 5(3), 349-361.

Sari, F. M., \& Putri, S. N. (2019). Academic WhatsApp Group: Exploring Students' Experiences in Writing Class. Teknosastik: Jurnal Bahasa dan Sastra, 17(2), 56-65.

Susilawati, F. (2017). Teaching Writing of Narrative Text through Digital Comic. Journal of English and Education, 5(2), 103111.

Utami, A. R., Aminatun, D., \& Fatriana, N. (2020). Student Workbook Use: Does It Still Matter To The Effectiveness of Students' Learning? Journal of English Language Teaching and Learning, 1(1),7-12. 


\section{BIOGRAPHY OF AUTHORS}

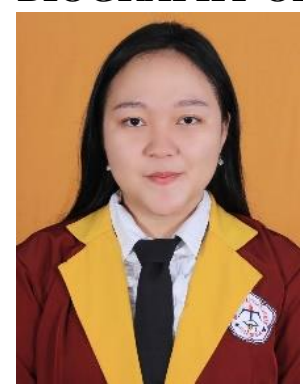

Evyta Tri Handayani is an active student in the English Education study program, Faculty of Arts and Education, Universitas Teknokrat Indonesia. During her study, she actively joins the students' organization. She was the Head Treasurer of HIMA PBI. Moreover, she has achieved the regional competition, such as a Runner Up of Micro Teaching Competition in Pekan Bahasa Sains dan Wirausaha 2018 in Universitas Teknokrat Indonesia.

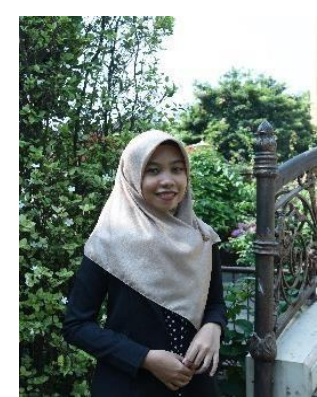

Dyah Aminatun is a lecturer in Universitas Teknokrat Indonesia with English Education as her background. Her research interests mostly focus on teaching media, ICT, and Teaching English as a Foreign Language. Last year, her research was funded by the Ministry of Research, Technology, and Higher Education for the program of Penelitian Dosen Pemula (PDP). Currently, she and her team are still working on a book to be published. Wish them luck! 